\title{
Kamu İnovatif Satın Alma Yöntemleri: Seçilmiş Ülke Örnekleri Kapsamında Bir Değerlendirme*
}

\author{
Innovative Public Procurement Methods: Examples Of Selected \\ Country And Lessons For Turkey
}

\author{
Elif Ayşe ŞAHIN IPEK ${ }^{1}$ \\ Ibrahim Attila ACAR ${ }^{2}$ \\ Mustafa ALPASLAN ${ }^{3}$
}

\section{ARTICLE INFO \\ Received: 24.01.2016 \\ Received in revised form: 23.03.2016 \\ Accepted: 11.04.2016 \\ Available online: \\ 26.12.2016 \\ JEL classification: \\ $\mathrm{H} 30, \mathrm{H} 57$ \\ Keywords: \\ Public Expenditures, \\ Innovative Public \\ Procurement, Public \\ Efficiency}

\begin{abstract}
A B S T R A C T
Innovative public procurement considered as demand-side policies aimed at economic competitiveness, growth and development through the development of private sector innovation supply. In this study it is examined the methods of innovative procurement policy and country examples. It is exerted obstacles and solutions from the results of this examination.
\end{abstract}

\section{MAKALE BILGISi}

Alındı: 24.01.2016

Gözden geçirilmiş

alındı: 23.03 .2016

Kabul: 11.04 .2016

Yayın: 26.12.2016

\section{Ö Z E T}

Kamu inovatif satın alma politikası, özel sektör inovasyon arzının geliştirilmesi suretiyle ekonomik rekabet edebilirliğin, büyüme ve kalkınmanın sağlanmasını amaçlayan talep yanlı politikalar kapsamında değerlendirilmektedir. Çalışmada kamu inovatif satın alma politikası yöntemleri ve seçilmiş ülke uygulamaları incelenmiştir. Bu inceleme

15-19 Mayıs 2016 tarihleri arasında düzenlenen 31. Türkiye Maliye Sempozyumu'nda sunulan metnin gözden geçirilmiş ve düzeltilmiş hâlidir.

1 Yrd. Doç. Dr. İzmir Katip Çelebi Üniversitesi IïBF Maliye Bölümü, elifasahin@gmail.com

2 Prof. Dr. İzmir Katip Çelebi Üniversitesi IïBF İktisat Bölümü, acar@ikc.edu.tr

3 Kalkınma Bakanlığı Yönetim Hizmetleri Genel Müdürlüğü İdari ve Mali İşler Şube Müdürlüğü, mustafa.alpaslan@kalkinma.gov.tr 
JEL Kodu:

$\mathrm{H} 30, \mathrm{H} 57$ sonucunda uygulamanın önündeki engeller ve çözüm önerileri ortaya konulmuştur.

Anahtar Kelimeler:

Kamu Harcaması,

Inovatif Satın Alma,

Kamuda Etkinlik

\section{Giriş}

Ekonomik rekabet gücünün arttırılmasında talep yanlı politikalar kapsamında değerlendirilen inovatif satın alma politikaları, özel sektörde inovasyonu geliştiren önemli paradigmalardan biri haline gelmiştir.

Öteden beri kamu satın almasının doğası ve büyüklüğü gereği, ekonomik ve sosyal kalkınmada önemli etkiler ortaya çıkarabileceği kabul edilmiştir (Watermeyer, 2010: 2).

Bununla birlikte küreselleşme sürecinin bugün geldiği noktada ortaya çıkan yeni rekabet anlayışında yenilikçilik ve farklılık yaratma, ülkeler açısından en önemli rekabet unsuru haline gelmiş (Kalkınma Bakanlığı, 2013: 5); bu da kamu satın alma stratejilerinin oluşturulması ve uygulanmasında inovasyonun gözetilmesi gereğini ortaya çıkarmıştır (Andes, 2010: 1). Nitekim günümüz gelişmiş ve gelişmekte olan ülkelerinin, bilim teknoloji ve yenilik stratejilerini oluşturup milli gelirden Ar-Ge harcamasına ayırdıkları payı hızla artırdıkları görülmektedir.

Kamu alımlarının Ar-Ge sistemi içindeki yeri ülkemizde de uzunca bir süredir tartışılmakla beraber, kamu inovatif satın alma politikası ilk defa Onuncu Kalkınma Planı ile birlikte detaylı olarak ele alınmış ve ülkemiz resmi politika gündemine girmiş bulunmaktadır.

Küresel rekabette, ülkemiz, 2011-2012 döneminde 142 ülke arasında bulunduğu 59. sıradan, 2013-2014 dönemi itibariyle 148 ülke arasından 44. sıraya yükselmiştir. Küresel Rekabet Raporu'na göre ülkemiz, "verimlilik odaklı ekonomi"den "yenilik odaklı ekonomi"ye geçiş sürecinde bir ülke olarak tanımlanmaktadır (Global Competition Report, 2014: 372). Bununla birlikte potansiyeli açısından ve diğer ülkeler ile karşılaştırmalı olarak değerlendirildiğinde, ülkemizde özel sektörün Ar-Ge ve inovasyondaki payı istenen düzeyde değildir. Nitekim GSYiH'den en fazla kaynağı \% 4,7 ile İsrail ve \% 3,4 ile Japonya ayırmaktadır. ABD'nin Ar-Ge'ye ayırdığı pay \% 2,7 iken AB $\%$ 1,8 düzeyinde bir kaynak ayırmaktadır. OECD'nin ortalamasının ise \% 2,3 ile $A B$ ortalamasının üzerinde kaldığı görülmektedir.

Türkiye'nin 2013 yılı itibariyle Ar-Ge'ye ayırdığı pay \% 0,92 düzeyindedir. Türkiye bu rakamı 2023 yılı itibariyle \%3 düzeyine çıkarmayı hedeflemektedir. Bu hedef inovasyon politikalarının farklı bakış açılarıyla desteklenmesini gerektirmektedir. Buna göre rekabet edebilirliğin güçlendirilmesi ve sürdürülebilirliğinin sağlanmasının en etkin yolu, yaratılan katma değer üzerindeki çarpan etkisi nedeniyle, Ar-Ge ve inovasyonun desteklenmesidir (Sanayi ve Ticaret Bakanlığı, 2007: 110). 
Ulusal düzeyde kamu inovatif satın alma politikası Sekizinci Beş Yıllık Kalkınma Planı'ndan itibaren gündemde olmakla beraber Sekizinci Beş Yıllık Kalkınma Planı'nda "Bilim ve Teknoloji Yeteneğinin Geliştirilmesi" başlı̆̆ altında daha genel ve yüzeysel bir şekilde ele alınmıştır. Genel bir ifadeyle, devletin satın alma politikasının ülkenin bilim, teknoloji ve sanayi yeteneğini geliştirecek yönde olacağı ifade edilmiş ve kamu tedarik politikası ile 2886 Devlet ihale Kanunu'nda Ar-Ge'ye dayalı tedarik için gerekli düzenlemeler yapılacağı belirtilmiştir.

Dokuzuncu Kalkınma Planı'nda ise sadece Ar-Ge ve yenilikçilik konuları üzerinde durularak Ar-Ge ve yenilikçilikle ilgili durum tespiti yapılmıştır. Bu doğrultuda Ar-Ge faaliyetlerinin çoğunlukla üniversiteler ve kamu kurumları tarafından gerçekleştirildiği, Ar-Ge faaliyetlerinin sonuçlarının uygulamaya geçirilemediği ya da yapılan araştırmaların genellikle sanayinin ihtiyaç ve talebinden uzak olduğu ifade edilmiştir. Bu çerçevede Dokuzuncu Kalkınma Planı döneminde inovasyon politikalarında ağırlık verilen uygulama ulusal ve bölgesel inovasyon sistemlerinin oluşturulması olmuştur.

Onuncu Kalkınma Planı ile birlikte ise, konunun daha detaylı bir şekilde ve etrafııca ele alındığı görülmektedir. Öncelikli olarak konu "Kamu Alımları Yoluyla Teknoloji Geliştirme ve Yerli Üretim Programı" başlığı altında incelenmiş ve doğrudan kamu satın alımlarına ve bu yolla teknolojinin geliştirilmesine atıfta bulunulmuştur. Söz konusu planda öncelikli olarak kamu alımlarının 2013 yılı itibariyle yaklaşık 105 milyar TL'ye ulaştığı ve bu rakamın GSYH'nin \% 7'sine karşılık geldiği ifade edilmekte ve bu oranın ülkenin Ar-Ge ve yenilik çalışmalarına katkı sağlaması açısından önemli bir fırsat olduğu değerlendirilmektedir. Ülkemizde, Kamu İhale Kanununda yerli istekliler lehine yüzde 15 oranına kadar fiyat avantajı yer almakla birlikte, mevcut sistemle kamu alımlarının teknoloji transferine ya da sanayinin gelişmesine yeterli düzeyde katkı sağlayamadığı kabulünden hareketle Onuncu Kalkınma Planı ile kamu alımlarının yeniliği, yerlileştirmeyi, teknoloji transferini ve yenilikçi girişimciliği teşvik edecek şekilde düzenlemesi amaçlanmaktır.

Program hedefleri kapsamında; orta-yüksek ve yüksek teknoloji nitelikli sektörlerde kamu alımları yoluyla teknoloji geliştirme, yüksek teknoloji sektörlerinde uluslararası alanda markalaşma sürecinin desteklenmesi ve markalaşmış ürün sayısının artırılması, kamu tedarik sistemi yoluyla Ar-Ge harcamalarının artırılması ve kamu alımlarında uygulanacak politikalarla uluslararası doğrudan yatırımların artırılması yer almaktadır.

Bu çerçevede gerçekleştirilmesi planlanan eylemlerden bazıları şunlardır:

- Kamu alımlarına yönelik uzun vadeli ihtiyaç planlaması yapılmasına imkân tanıyan analiz çalışmaları yapılacaktır.

- Ihtiyaç planlamasıyla bütçe ve yatırım süreci arasında eşgüdüm sağlanacaktır.

- Kamu Alımları Bilgi Sistemi altyapısına yönelik çalışmalar yapılacaktır.

- Yüksek teknolojili ürünlerde kamu alım garantisine dayalı üretim yapılması için model geliştirilecek ve ihtiyaç duyulan mevzuat düzenlemesi yapılacaktır. 
- Kamu alımlarında fiyat avantajı sağlanacak olan orta-yüksek ve yüksek teknolojili ürün listesi hazırlanacaktır.

- Sivil alanlarda sanayi işbirliği programı uygulamaları içeren mal ve hizmet alımları için finansman ve organizasyon modeli oluşturulacaktır.

- Kamu kurum ve kuruluşlarının toplulaştırılabilecek ve bu yolla fiyat avantajı sağlanabilecek nitelikteki mal ve hizmet ihtiyaçlarının merkezi tedarik yoluyla satın alınabilmesi yönünde çalışmalar yapılacaktır.

- Kamu İhale Kanunu ve ilgili mevzuatta yerli üretim, yenilik ve teknoloji transferini teşvik edecek şekilde düzenleme yapılacaktır.

- Kamu alımlarında KOBi'lerin payının arttırılmasına yönelik tedbirler alınacaktır.

- Kamu alımlarında koordinasyon mekanizması geliştirilecektir.

- Kurum ve kuruluşların bu dönüşüm programını uygulamak için eksik olan kapasiteleri geliştirilecektir.

- Farkındalık ve bilgilendirme faaliyetleri yürütülecektir.

Görüldüğü üzere Onuncu Kalkınma Planı ile kamu satın alma politikalarının inovasyonu geliştirecek şekilde ele alınması gerektiği konusunda açık bir politika beyanı bulunmaktadır. Bu politika beyanında 64. Hükümet Eylem Planın'da da yer verilmiştir.

Bu çalışmanın amacı ülkemiz uygulamalarına temel oluşturması açısından kamu inovatif satın alma politikası yöntemlerinin ve seçilmiş ülke uygulamalarının incelenmesini oluşturmaktadır. Buradan elde edilecek çıkarımların kamu inovatif satın alma politikası açısından ülkemiz literatürüne ve uygulamalarına katkı sağlaması beklenmektedir.

\section{2. İnovasyon ve İnovasyonun Kalkınmada Önemi}

Latince "innovatus"tan türemiş bir sözcük olan inovasyon, en geniş anlamıyla, bilginin ekonomik ve toplumsal faydaya dönüştürülmesi şeklinde tanımlanabilir (Elçi ve diğerleri, 2008: 25, 26).

OECD ve Avrupa Komisyonu'nun birlikte yayınladığı Oslo Kılavuzu'nda inovasyon; "yeni veya önemli ölçüde değiştirilmiş ürün (mal ya da hizmet) veya sürecin; yeni bir pazarlama yönteminin; ya da iş uygulamalarında, işyeri organizasyonunda veya dış ilişkilerde yeni bir organizasyonel yöntemin uygulanmasıdır." şeklinde tanımlanmaktadır (OECD, 2004).

Inovasyon, hem ülkeler hem de firmalar için ulusal ve uluslararası alanda rekabet gücü kazanmanın, verimlilik artışı sağlamanın, ekonomik büyüme ve gelişmenin, dolayısıyla da refah ve yaşam kalitesi artışının en temel unsurlarından biri olarak kabul edilmektedir. Buna göre, ülkenin sahip olduğu inovasyon yapma gücü başta ekonomik büyümeyi sağlarken, buna bağlı olarak ülkenin vatandaşlarına sunduğu 
hizmetlerde de olumlu gelişmeler söz konusu olmaktadır. Bu sürecin sonucunda bireylerin yaşam kaliteleri de yükselmektedir (Işık ve Kılınç, 2011: 14, 16).

Dulupçu (2006), bilgi ekonomisinde kalkınmanın anahtarının inovasyon olduğunu belirtmektedir (Dulupçu, 2006: 240).

Albeni ve Karaöz (2003), günümüz bölgesel büyüme ve kalkınma süreçlerinde bilginin en önemli kaynak, öğrenmenin en önemli süreç ve inovasyonun en önemli sonuç olarak değerlendirildiğini vurgulamışlardır (Albeni ve Karaöz, 2003: 159). Dolayısıyla inovatif niteliğin yaygınlaşması, belirli destek ve uygulamalarla hız kazanacaktır. Bunun için kamu otoritesinden kaynaklanan uygulamalar en önemli araç haline dönüşebilmektedir.

\section{Kamu İnovatif Satın Alımı ve İnovasyon Politikalarındaki Yeri}

İnovasyon açısından kamu satın alması değerlendirildiğinde;

i) inovasyon içermeyen standart ürünlerin satın alınması ile

ii) inovasyonel bir politika aracı olarak inovatif satın alma şeklinde iki tür gözlenmektedir (Aschhoff ve Sofka, 2008: 2).

Kamu satın alma sürecinde, "kamu sektöründeki organizasyonlar veya devlet tarafından tedarik edilen mal ve hizmetlerin kalite, miktar, zaman, yer ve fiyat gibi beş doğruyu sağlaması gerekmektedir (Burmaoğlu v.d., 2010: 3). İnovatif kamu satın almasında öne çıkan özellik, kamu kurumları tarafından satın alma faaliyetlerinin inovasyona yol açacak şekilde gerçekleştirilmesi şeklinde ifade edilir (Rolfstam, 2012: 303).

Bu açıklamalardan hareketle kamu inovatif satın almasını; "bir kamu kurumu tarafından, belirli bir zamanda, mevcut olmayan, ancak makul bir sürede üretilebilir olan bir ürün veya sistem için sipariş oluşturulması olarak ifade etmek mümkündür. Alıcının bu isteğinin gerçekleştirilmesi için ilave veya yeni bir teknoloji geliştirme çalışması/çabası gereklidir." (Edquist ve Hommen, 1998: 4).

Benzer bir tanımına göre kamu inovatif satın alması "talep yanlı bir politika aracı olarak henüz mevcut olmayan ya da tamamen yeni olmasa da tasarım ve üretimi teknoloji geliştirme çalışmaları gerektiren ürün ve sistemlerin satın alınması" şeklinde tanımlanabilir (Aschhoff ve Sofka, 2008: 2).

Kamu inovatif satın almasının aksine, kamu geleneksel satın alması kamu kurumlarının, kalem ve kağıt gibi, Ar-Ge içermeyen basit ve hazır ürünleri satın alması şeklinde gerçekleşir. Satıcının seçilmesinde ilgili ürünün fiyat ve kalitesi dikkate alınmaktadır (Edquist ve Hommen, 1998: 4). Ancak kamu kesiminin tedarikçi seçiminde aşırı fiyat odaklı olması, piyasa yapısını inovasyon bakımında da etkilemektedir. Sürekli en düşük fiyatı teklif eden tedarikçinin seçilmesinin uzun vadede inovasyonun gelişimini olumsuz yönde etkilediği düşünülmektedir (Ünübol, 2012: 44). Kamu inovatif satın alma sürecinde ideal olarak, talep edilen ürün (mal veya hizmet) veya sistemden beklenen fonksiyonel özellikler tanımlanırken, söz konusu ürün veya sistemin tasarımına yer verilmez. Ancak bu sayede kamu satın alımının inovasyonu tetikleyeceği 
düşünülmektedir. Firmaların bu ihtiyaçları karşılamak üzere ihaleye başvurmaları sonucunda aralarından seçilecek bir firma talep edilen ürün veya sistemin üretiminden sorumlu olacaktır. Bu sebeple bu yöntemin rekabetçi bir yöntem olduğu kabul edilir (Aschhoff ve Sofka, 2008: 2).

Basit ve hazır mal ve hizmetlerin tedarikinde kullanılan konvansiyonel kamu alımı yönteminde, ihale öncesi hazırlanan şartnamelerde girdiler üzerine yoğunlaşılırken, inovatif kamu alımı fonksiyon üzerine yoğunlaşır ve çıktıların tasarımına yer vermez. Bu sayede yenilikçi üretimin önü açılır.

Geleneksel kamu satın almasının aksine, kamu inovatif satın alması kullanıcıüretici etkileşiminin özel bir türünü oluşturur. Buna göre kamu inovatif satın alma süreci kullanıcı ve üretici arasında işbirliği ve bilgi paylaşımını gerektirir (Gavras ve diğerleri, t.y.: 11).

\subsection{Kamu İnovatif Satın Alımının Ulusal İnovasyon Politikalarındaki Yeri}

Avrupa Komisyonu 2003 Raporu'na göre AR-GE faaliyetlerinin ve inovasyonun arttırılmasına ilişkin geliştirilen politikalar;

i) dolaylı önlemler,

ii) doğrudan önlemler,

iii) garanti mekanizmaları,

iv) risk sermayesi şeklinde sınıflandırılabilir.

Doğrudan önlemler; "arz-yanlı" ve "talep-yanlı" olmak üzere ikiye ayrılır. Geleneksel olarak arz-yanlı politikalara ağırlıklı olarak yer verilirken talep-yanlı politikalar günümüzde büyük bir ilgi çekmektedir (Nyri ve diğerleri, 2007: 11, 12). Talep-yanlı politikalar arz-yanlı politikaların tamamlayıcı bir parçası olarak görülmektedir. Aşağıda yer verilen Şekil-1'de inovasyonu geliştirmeye ilişkin başvurulan yöntemlerden talep yanlı politikalar ve kamu satın alma politikasının bu politikalar içerisindeki yeri şematize edilmiştir.

Şekil 1: Kamu Satın Alma Politikasının Talep Yanlı Politikalar İçerisindeki Yeri

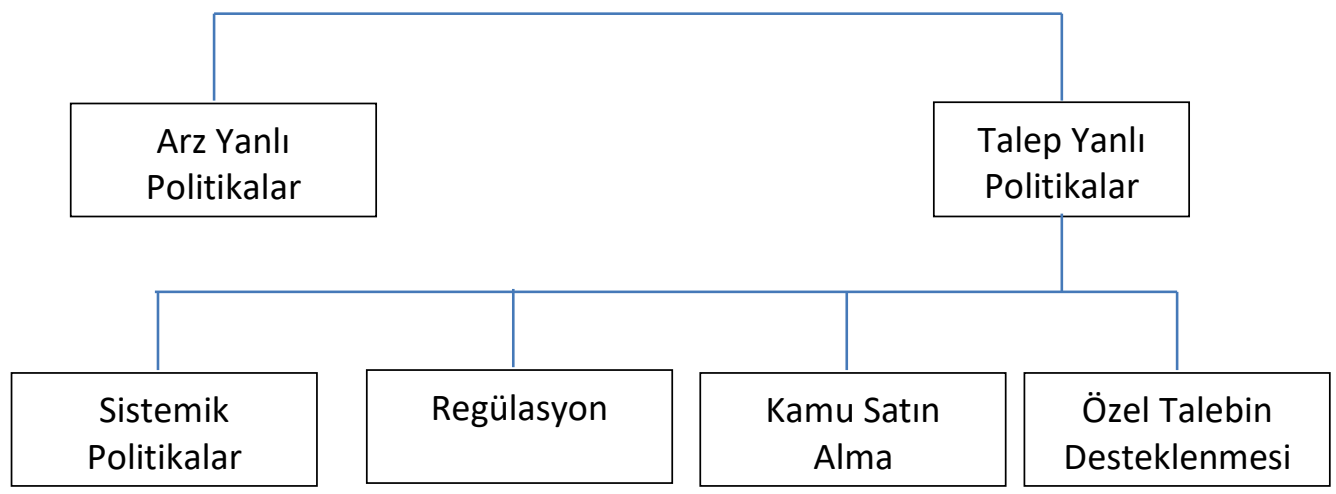

Kaynak: (Wintjes, 2011)'den yararlanılarak tarafımızca hazırlanmıştır. 
Arz yanlı politikalar maddi ve maddi olmayan kaynakların kamu tarafından sağlanması ile ilişkilendirilirken, talep yanlı politikalar inovatif ürün ve hizmetler için piyasaların etkilenmesi ile ilişkilendirilerek açıklanmaktadır. Özel sektör inovasyon faaliyetlerinin kamu kesimi tarafından desteklenmesinde özel sektör inovasyon sürecine ilave girdiler sağlayan araçlar kullanılabileceği (arz yanlı araçlar) gibi inovasyon çıktılarını etkileyen araçlardan faydalanılması (talep yanlı) söz konusu olabilir (Aschhoff ve Sofka, 2008: 3).

Buna göre özel sektör inovasyonunun geliştirilmesinde arz yanlı politikalar "mali kaynaklar" ve "hizmetler" şeklinde ikiye ayrılabilir. Mali kaynaklar içerisinde genellikle araştırma altyapılarına yapılan yatırımlar ve bu altyapıların operasyonel giderlerinin performans esasına dayalı olarak finanse edilmesi, proje destek programları, araştırmacı insan gücü yetiştirme programları, üniversite-sanayi işbirliğini destekleyen hibe programları ile araştırma-geliştirme faaliyetlerinin desteklenmesi için verilen diğer hibe, teşvik ve mali destekler yer almaktadır. Hizmetler, diğer bir deyişle mali olmayan destekler içerisinde ise araştırma ağ yapılarının oluşturulması ile bilgi desteğinin verilmesi anlaşılmaktadır.

Özel sektör inovasyonunun geliştirilmesinde talep yanlı politikalar ise Şekil-1'de görüleceği üzere;

i) Sistemik Politikalar,

ii) Regülasyonlar,

iii) Kamu Satın Alma Politikası,

iv) Özel Talebin Desteklenmesi şeklinde sınıflandırılmaktadır.

"Sistemik politikalar" içerisinde kümelenme politikaları ile tedarik zinciri politikaları ele alınmaktadır. "Regülasyonlar" başlığı altında inovasyon hedeflerinin belirlenmesine ilişkin gerçekleştirilen düzenlemeler ile teknolojik gelişimin koordine edilmesi amacıyla oluşturulan platformlar incelenmektedir. "Özel talebin desteklenmesi" ile vergi teşviki yolu ile talebin desteklenmesi gibi mali destekler ile farkındalığın arttırılmasına ilişkin olarak yapılan faaliyetler aracılığıyla talebin arttırılması gibi mali olmayan destekler ele alınmaktadır. "Kamu satın alma politikası" ile Ar-Ge satın alması ve/veya inovatif ürün veya sistemin satın alınması yolu ile özel sektör inovasyonunun geliştirilmesi hedeflenmektedir (Wintjes, 2011).

Esasen kamu satın alma politikası yolu ile özel sektör inovasyonunun geliştirilmesine ilişkin yaklaşımlar yeni değildir. Buna göre 1970'li yıllarda, bazı çalışmalarda kamu inovatif satın alma politikalarının anlamına yer verilmiş olmakla birlikte, özellikle Avrupa Birliği'nde kamu satın alımının bir politika aracı olarak kullanılması fikrine sıcak bakılmamıştır. Bu eğilim 2000'li yıllara kadar devam etmiş, ancak, arz-yanlı politikaların tek başına inovasyonu arttırmadaki yetersizliği, özel sektör inovasyonunun arttırılmasında talep yanlı politikalara ilginin yeniden doğmasına neden olmuştur.

Hekker ve diğerleri (2007) teknolojik kalkınmanın sağlanmasında inovasyon sisteminin barındırması gereken 7 temel fonksiyonu; 
i) Girişimcilik faaliyeti,

ii) Bilginin geliştirilmesi,

iii) Bilginin yayılması,

iv) Araştırmalara rehberlik edilmesi,

v) Piyasa oluşturma,

vi) Kaynakların mobilizasayonu,

vii) Meşruiyetin sağlanması şeklinde sıralamıştır.

Kamu inovatif satın alması bu fonksiyonlardan özellikle birinci, beşinci ve altıncı fonksiyonlara katkıda bulunarak inovasyon sisteminin başarılı bir şekilde işlerlik kazanmasına yardımcı olacaktır. Buna göre kamu inovatif satın alması yolu ile yeni piyasaların oluşturulması ve kaynakların mobilizasyonu sağlanarak girişimcilik faaliyetlerine güç kazandırılması beklenmektedir (Stuyt, 2011: 12, 13).

\subsection{Kamu İnovatif Satın Alma Politikasının Rasyonalitesi}

Kamu satın almasının inovasyonu desteklemek üzere kullanılmasının rasyonalitesi şu şekilde sıralanabilir (Edler ve Georghiou, 2007: 954):

i) Kamu satın alması yerel talebin önemli bir kısmını oluşturmaktadır ve çok uluslu işletmeler yer seçimi kararlarında yerel talebin nicelik ve niteliğine önemli ölçüde yer verirler.

ii) Toplumsal ihtiyaçların inovatif ürünlere dönüştürülmesinde söz konusu olabilen piyasa başarısızlıklarına karşın kamu satın alması etkili bir yöntem olarak değerlendirilebilir.

iii) İnovatif çözümlerin satın alınması kamu altyapısı ve kamu hizmetlerinin geliştirilmesinde maliyet-etkinliğin sağlanması açısından etkili bir yol olarak değerlendirilebilir.

Inovasyon faaliyetlerinde toplumun ihtiyaç duyduğu seviyeye ulaşmanın kamu satın alma politikaları yolu ile desteklenmesi iktisat teorisinde "piyasa başarısızlığı teorisinde" yerini bulmaktadır. Buna göre özel sektörün kendi haline bırakıldığında toplumun ihtiyacından daha az Ar-Ge (ve dolayısıyla inovasyon) yapacağı varsayımı kabul edilmektedir. Özel sektörün neden ihtiyaçtan daha az Ar-Ge yapacağına dair birkaç faktör öne çıkmaktadır. Bunlardan en önemlisi, Ar-Ge'nin riskli bir yatırım olmasıdır ve genellikle her Ar-Ge projesinde, büyük yatırımlar yapılsa bile projenin olumlu bir sonuç doğurmama, yeni bir buluşla sonuçlanmama ve akabinde yüksek gelir yaratamama ihtimali çok yüksektir.

Ar-Ge sürecindeki belirsizlikler sadece Ar-Ge yapan şirketlerin maliyetini çıkaracak bir buluşa dönüşmeme olasılığıyla sınırlı değildir. Proje başarılı sonuçlanıp bir buluşa dönüşse bile süreç belirsizliklerle doludur. Henüz piyasası oluşmamış yeni bir 
ürünün nasıl fiyatlanacağı, talebin ne ölçüde olacağı ve ürünün piyasa değeri belirsizliğin başka bir boyutudur.

Özel sektörün toplum gerekliliğinin altında bir Ar-Ge performansı sergilemesinin bir sebebi de, "taşma etkileri", yani bir şirketin yaptığı Ar-Ge faaliyetinden diğer şirketlerin de dolaylı olarak fayda sağlamasıdır. Taşma etkileri, aynı veya farklı sektörlerden şirketlerin birbirlerinin buluşlarından tersine mühendislik, taklit, ticari ilişkiler, patentler gibi yöntemlerle faydalanmasına dayanır. Bu eylemlerdeki ortak nokta, Ar-Ge'nin bir kamu malına dönüşmesi ve mal sahibinin ürünün getirisinden ancak kısmi olarak faydalanabilmesi sonucunun ortaya çıkmasıdır (Güçeri ve Karaman, 2013: 3, 4).

Kamu kurumları satın alma yolu ile inovasyonu desteklemek üzere;

i) Modern ürün ve sistemler için yeni piyasaların oluşturulması,

ii) İhtiyaçlarını fonksiyonel ve performans bakımından açıklayarak talep havuzunun oluşturulması,

iii) İnovatif ürünler için test alanı oluşturulması,

iv) Yeni teknoloji ve çözümler için lider piyasaların oluşturulması şeklinde çeşitli etkiler yaratabilir (Kattel ve Lember, 2010: 377).

Yülek ve Tiryakioğlu'na (2013: 1) göre destek ve teşviklerle yönlendirilecek teknolojik gelişme alanları kamu alımları ile tamamlandığında pazarlama ve dolayısıyla finansman sorununu minimize eden yerli sanayi, üretim kapasitesi ve yetenekleri itibariyle derinleşme yaşamaktadır. Nihayet kamu alımları, belli alanlardaki teknolojik gelişme ve faaliyetleri desteklemek ve teşvik etmekten daha kapsamlı ve sürdürülebilir bir sanayi politikası aracı olarak kullanılmaktadır.

Bu varsayımların ardında kamu kesimi inovasyon talebinin çarpan etkisiyle özel sektör Ar-Ge ve inovasyon yatırımlarını arttıracağı ve sonuçta ülkelerin rekabet edebilirliklerinin gelişeceği düşüncesi yer almaktadır. Buradan yola çıkarak kamu satın alma politikalarının özel sektör Ar-Ge ve inovasyon yatırımlarını arttıracak şekilde ele alınması küresel rekabet gücü ve kalkınmanın sağlanmasında öne çıkan politika önerilerinden birisidir.

\subsection{Kamu İnovatif Satın Almasının Türleri}

Inovasyon politikasında belirlenen stratejiye göre kamu inovatif satın alması çeşitli şekillerde gerçekleştirilebilir. Buna göre kamu inovatif satın alımı, satın almanın organizasyonuna göre "genel" veya "stratejik satın alma" şeklinde; satın alınan ürün veya sistemin kullanıcılarına göre "doğrudan satın alma", "katalitik satın alma" ve "işbirlikçi satın alma" şeklinde sınıflandırılabilir. Bunlara ilave olarak kamu inovatif satın alması inovasyonun etki alanına göre ve inovasyon sürecine göre çeşitli sınıflandırmalara konu olabilir (Tablo-1). Bu kısımda kamu inovatif satın almasının bu sınıflandırma türlerine göre açıklamalarına yer verilmiştir. 
Tablo 1: Kamu İnovatif Satın Alma Türleri

\begin{tabular}{|c|c|c|c|}
\hline $\begin{array}{l}\text { Organizasyonuna } \\
\text { Göre Sınıflandırma }\end{array}$ & $\begin{array}{l}\text { Kullanıcılarına Göre } \\
\text { Sınıflandırma }\end{array}$ & $\begin{array}{l}\text { İnovasyonun Etki } \\
\text { Alanına Göre } \\
\text { Sınıflandırma }\end{array}$ & $\begin{array}{l}\text { İnovasyon Sürecine } \\
\text { Göre Sınıflandırma }\end{array}$ \\
\hline $\begin{array}{l}\text { 1. Genel Inovatif Satın } \\
\text { Alma }\end{array}$ & $\begin{array}{l}\text { 1. Doğrudan Satın } \\
\text { Alma }\end{array}$ & $\begin{array}{l}\text { 1. Yaratım Odaklı Satın } \\
\text { Alma }\end{array}$ & $\begin{array}{l}\text { 1. Ar-Ge Satın Alması } \\
\text { 2. Inovatif }\end{array}$ \\
\hline $\begin{array}{l}\text { 2. Stratejik Inovatif Satın } \\
\text { Alma }\end{array}$ & $\begin{array}{l}\text { 2. Katalitik Satın Alma } \\
\text { 3. İşbirlikçi Satın Alma }\end{array}$ & $\begin{array}{l}\text { 2. Difüzyon Odaklı Satın } \\
\text { Alma }\end{array}$ & $\begin{array}{l}\text { Ürün/Sistemin Satın } \\
\text { Alınması }\end{array}$ \\
\hline
\end{tabular}

\subsubsection{Organizasyonuna Göre Sınıflandırma}

Kamu inovatif satın alması inovatif satın almanın organizasyonu ve yönetimine göre "genel" veya "stratejik" satın alma biçiminde gerçekleştirilebilir.

Genel satın alma (general procurement) yöntemine göre, kamu satın almasının inovasyon aracı olarak kullanılmasında, kamu satın alması genel olarak organize edilmiş olabilir ve ihale başvurularının kabul edilmesinde ve değerlendirilmesinde inovasyon temel kriter olarak belirlenmiş olabilir. Genel olarak, inovasyon politikasından doğrudan sorumlu olmayan, İçişleri veya Maliye Bakanlıkları gibi bakanlıklarda bulunan merkezi satın alma ofisleri sorumludur.

Stratejik satın alma (strategic procurement) yöntemine göre, amaçlanan belirli bir piyasanın güçlendirilmesi için belirli teknolojilerin, ürün veya hizmetlerin geliştirilmesidir. Stratejik satın alma yöntemi, belirli sektörel politikalarla ilişkilendirildiğinden ilgili sektörlerin bakanlıkları aracılığıyla koordine edilir (Gavras ve diğerleri, t.y.: 19).

\subsubsection{Kullanıcılara Göre Sınıflandırma}

Kamu inovatif satın alma yöntemine başvurulmasının nihai amacı kamu otoritelerinin ve kurumlarının ihtiyaçlarının karşılanması değildir. Buna göre kamu kesimi tarafından satın alınan ürün, hizmet veya sistemler sadece kurumların görevlerini yerine getirmesi amacına hizmet etmeyip, aynı zamanda özel kesimde yer alan tüketicilerin taleplerini etkilemeye ve karşılamaya yönelik olabilir. Bununla birlikte bazı durumlarda tek amaç, özel sektörde yer alan tüketicilerin ihtiyaçlarının karşılanması olabilir. Bu sebeple, kamu inovatif satın alması yolu ile elde edilen ürün, hizmet veya sistemlerin kullanıcısına göre bir sınıflandırma yapılması mümkündür. Bu açıdan; "doğrudan satın alma" (direct procurement), "işbirlikçi satın alma" (cooperative procurement), "katalitik satın alma" (catalytic procurement) şeklinde bir sınıflandırma yapılması mümkündür (Gavras ve diğerleri, t.y.: 20).

Doğrudan satın alma (direct procurement) yönteminde, ihaleye çıkan kamu kurumu veya otoritesi satın alma sonucu elde edilen ürün, hizmet veya sistemin nihai kullanıcısı durumundadır ve ihaleye çıkmasındaki temel motivasyon kaynağı yasal görevlerinin yerine getirilmesi amacıyla kendi ihtiyacının karşılanmasıdır. 
Katalitik satın alma (catalytic procurement) yöntemine göre, satın alma ihaleye çıkan kamu otoritesi veya kurumundan ziyade satın alınan ürün, hizmet veya sistemin nihai kullanıcısı adına gerçekleştirilir. Buna göre ihaleye çıkılmasında temel motivasyon toplumsal ihtiyaçların karşılanmasıdır. Burada amaçlanan özel tüketicilere yeni veya alternatif ürün, hizmet veya sistemleri satın alma imkanının verilmesidir. Yeterli talebin oluşması sayesinde yeni bir piyasanın oluşturulmasına katkıda bulunulacak ya da mevcut piyasaların geliştirilmesi sağlanacaktır.

İşbirlikçi satın alma (co-operative procurement) yöntemi, kullanıcı grubuna göre yapılan sınıflandırmada karma yöntemi ifade eder. Buna göre kamu inovatif satın alımına çıkılmasının motivasyon kaynağı hem ihaleye çıkan kurumun ihtiyaçları, hem de nihai tüketicilerdir. İşbirlikçi satın alma yöntemi, satın alınan inovasyondan, genellikle kamu otoriteleri veya kurumlarının özel alıcılarla birlikte faydalanması sonucu ortaya çıkar.

\subsection{3. İnovasyonun Etki Alanına Göre Sınıflandırma}

Yaratıcılık odaklı satın alma (creation oriented) yöntemi, yeni ürün, hizmet, sistem veya sürecin oluşturulduğu satın alma yöntemidir. Difüzyon odaklı satın alma (diffusion oriented) yönteminde ise, dünya için yeni olmayan, ancak söz konusu ülke için yeni olan ürün, hizmet, sistem veya sürecin satın alınması söz konusudur. Difüzyon odaklı satın alma yönteminde satın alınan inovasyonun ülke için yeni olmasının yanı sıra, söz konusu inovasyonun ülke şartlarına adapte edilmesi söz konusudur.

\subsection{4. İnovasyon Sürecine Göre Sınıflandırma}

Ticarileştirme öncesi satın almanın (pre-commercial procurement) altında yatan temel düşünce, bu satın alma yönteminin çok daha fazla Ar-Ge ihtiyacı olan inovatif ürün ve hizmetleri hedef almasıdır. Bu sayede alıcı ile potansiyel satıcılar arasında teknoloji riski paylaşılmış olur. Bu yöntem ile taraflar arasında gerçekleştirilen sözleşme inovatif ürünün keşfi ve fizibilite çalışmasından prototipinin oluşturulmasına ve ticarileştirilmesine kadar geçen çok aşamalı bir süreçteki Ar-Ge faaliyetlerini kapsar. Bu yönü, yöntemi ticarileştirilmiş ürün, hizmet veya sistemlerin satın alma (commercial procurement) yönteminden ayırır ve alıcı ile satıcı arasında daha fazla işbirliği ve diyalog gerektirdiği için alıcıya daha fazla hareket alanı bırakmaktadır. Bununla birlikte bu yöntemde monopolcü yapıların ortaya çıkmasının engellenmesi için alan araştırması aşamasında en az iki rakip satııının bulunması gerektiği önerilir (Edler ve Georghiou, 2007: 954).

Inovasyon sürecine göre yapılan sınıflandırmada ticarileştirme öncesi satın alma yönteminin kamu inovatif satın alma yöntemleri arasında değerlendirilip değerlendirilmemesi gerektiği konusunda tartışmalar mevcuttur. Bu tartışmalara göre ticarileştirme öncesi satın alma yöntemi inovasyonun arttırılmasında talep-yanlı bir politika olmaktan ziyade Ar-Ge yatırımlarını arttırmaya yönelik arz-yanlı politikalar içerisinde değerlendirilmektedir. Bu düşünceye göre ticarileştirme öncesi satın alma 
yöntemi sonucunda tedarikçilerin sürecin sonucunda inovatif ürün üretip üretmeyeceği tamamiyle piyasa koşullarına terkedilmekte ve dolayısıyla inovasyonun geliştirilmesinde katkısı inovatif ürün/sistemlerin satın alınmasına göre sınırlı düzeyde kalmaktadır.

Bu tartışmalara karşın ülke uygulamaları incelendiğinde, ülkelerin ağırlıklı olarak, ticarileştirme öncesi satın alma yöntemine yer verdikleri görülmektedir. Bu durumun altında yatan sebeplerden en belirgin olanı söz konusu ülkelerde mevcut firmaların inovasyon üretme konusundaki sınırlılıkları olarak değerlendirilebilir. Bununla birlikte ülkeler de kamu inovatif satın alma yöntemleri konusunda bir öğrenme sürecinden geçmektedir.

Öte yandan bu sınıflandırma türlerinden hangi yöntemin belirleneceği ülkenin inovasyon potansiyeline göre belirlenen inovasyon stratejisi çerçevesinde verilecek bir karardır. Bununla birlikte kamu inovatif satın alma türlerinden hangileri kabul edilirse edilsin kamu alıcıları;

i) Rekabet eden sosyo ekonomik hedefler, ulusal ekonomik çıkarlar, bölgesel ve uluslararası ticaret sözleşmelerinin öngördüğü küresel rekabet koşulları arasındaki dengenin gözetilmesi;

ii) Kamu alımlarında tarafsızlık, eşitlik ve saydamlık ilkelerine uyulması;

iii) Rekabetin korunması ve geliştirilmesi;

iv) Ihale verimliliğinin sağlanması için yeni teknolojilerden faydalanılması gibi pek çok unsura dikkat ederek hareket etmek durumundadır (Rolfstam, 2014: 10).

\section{Seçilmiş Bazı Ülkelerde Kamu İnovatif Satın Alma Politikası}

\section{1. İsveç}

Pek çok ülkede, uzun yıllarca, talep yanlı politika araçları inmal edilmiştir. Bu durum kamu inovatif satın alımları için de geçerlidir. Ancak, İsveç bu açıdan 1900'lerin ortasından 1980'lere kadarki dönemde büyük bir geçmişe sahiptir. Buna göre altyapı gelişmi ile ilgili ilk elektronik haberleşme akımı (AXE), mobil telefon sistemi (Televerket/Ericsson), hızlı tren sistemi gibi inovatif çözümler ile savunma ile ilgili hafif savaş uçağı gibi inovatif çözümler inovatif kamu satın alımının başarısına ilişkin ilk örnekler olarak gösterilmektedir (Edquist, 2009: 8). İsveç'in geçmişindeki bu uygulamalar kamu inovatif satın alma yöntemlerinden stratejik satın alma ve ticarileştirilmiş inovatif ürünlerin satın alınması yöntemlerine örnek gösterilmektedir.

İsveç'te kamu inovatif satın alma politikaları adem-i merkezi olarak yürütüldüğü gibi- bu uygulamanın en bilinen ve başarılı örneği Enerji Bakanlığı'nın inovatif satın alma politikalarıdır- merkezi olarak da yürütülmektedir.

Enerji Bakanlığı'nın inovatif kamu satın alımı yaklaşımı "piyasanın enerji-etkin (energy-efficient) teknolojilere dönüştürülmesi" olarak ifade edilmektedir ve PPI programı enerji vergileri, araştırma-geliştirme programları, müşteri bilgilendirme ve eğitim programları, etkinlik standartları, temel talep eğitimi, sözleşmeler şeklinde 
sıralanan diğer araçlarla bütünleşik olarak yürütülmektedir. İsveç Enerji Bakanlığı uygulamakta olduğu kamu inovatif satın alımlarını "teknoloji (ticarileştirilmiş inovatif ürün/sistemlerin) satın alımı" olarak tanımlıyor olmakla birlikte, bu satın alımların aynı zamanda güçlü sosyal amaçları barındırıyor olması, pek çok akademik çalışmada söz konusu satın alımların "stratejik satın alma" olarak tanımlanmasına neden olmaktadır.

Diğer sınıflandırmalar açısından, Enerji Bakanlığı satın alımlarda özel sektörle işbirliği içerisinde hareket etmektedir (işbirlikçi satın alma -co-operative procurement). Ancak bazı durumlarda "katalitik satın alma" yöntemine de başvurulmaktadır. Bununla birlikte, inovasyonun ticarileştirilme aşamasının desteklenmesi temel amaç olmakla birlikte, satın alınacak teknolojiye göre ticarileşme öncesi satın alma ve ticarileştirilmiş ürünlerin satın alımı yöntemleri kullanılmaktadır (Stuyt, 2011).

Kamu inovatif satın alma politikalarının merkezi olarak koordine edilmesinden sorumlu kuruluş VINNOVA'dır. VINNOVA, 2001 yılında, Girişim, Enerji ve Iletişim Bakanlığı'na bağlı bir kuruluş olarak kurulmuştur (VINNOVA, 2015).

VINNOVA ticarileştirme öncesi inovatif satın alma modelini uygulamaktadır. Bununla birlikte katalitik satın alma yöntemini de kullanmaktadır. Buna göre VINNOVA 2010-11 döneminde "Kamu İnovatif Satın Alma Destek Programı" (Public Innovation Procurement Support Program" başlatmıştır. Bu program ile VINNOVA kamu alıcılarına piyasa danışmanlığı, inovasyon satın alımı sürecinin hazırlanması (teknoloji satın alımı veya ticarileştirme öncesi satın alma şeklinde olabilir) konularında katalist rolünü üstlenmektedir. Bu rolü kapsamında ayrıca KOBi'lerin programa katılmasını teşvik etmektedir. Program kapsamında VINNOVA satın alma sürecinin maliyetlerinin \%50'sine kadar oranda mali destek de sağlamaktadır. 2011 yılı itibariyle sağlanan toplam mali destek 1 milyon Euro tutarındadır (EC, 2015).

VINNOVA ile gerçekleştirdikleri işbirliği kapsamında, 2014 yılından itibaren, İsveç Rekabet Kurumu İnovasyon Satın Alımında Metodoloji Desteği ve Rehberi'ni (Methodology Support and Guidelines for Innovation Procurement) yayınlamıştır (Konkurrensverket, 2015).

\section{2. İngiltere}

\subsubsection{Ulusal İnovatif Satın Alma Politikası}

İngiltere'de merkezi anlamda satın alma politikalarının inovasyonu geliştirme amaçlı kullanılmasına ilişkin çalışmalar 2003 yılında Ticaret ve Sanayi Bakanlığı'nın ${ }^{4}$ raporu ile başlamıştır. 2007 yılında İnovasyon, Üniversite ve Yetenek Bakanlığı (Department for Innovation, Universities and Skills) İnovatif Çözümler Bulma ve Satın Alma (Finding and Procuring Innovative Solutions) Rehberi ile inovatif satın alma konusunda öneriler getirmiştir. Bu rehberde inovatif satın alma kamu kurumlarının

\footnotetext{
4 Ingiltere'de Ticaret ve Sanayi Bakanlığı (Department of Trade and Industry) önce İnovasyon, Üniversite ve Yetenek Bakanlı̆̆ı'na (Department for Innovation, Universities and Skills) dönüştürülmüş ardından şimdi adıyla İşletme, İnovasyon ve Yetenek Bakanlığı'na (Department for Business, Innovation and Skills) dönüştürülmüştür.
} 
tercihine bırakılmış inovatif çözümler gerektiren toplumsal ihtiyaçların belirlenmesine özel bir önem verilmiştir. İnovatif satın almayı tercih eden diğer bakanlıklara söz konusu bakanlık tarafından teknik destek verilmiştir.

2008 yılında yayınlanan İnovasyon Ulusu (Innovation Nation) isimli beyaz kitapla, bakanlıklara Inovatif Satın Alma Planı (Innovation Procurement Plan) hazırlanması zorunluluğu getirilmiştir. Bu plan ile bakanlıkların satın alma uygulamalarının merkezine inovasyonu yerleştirecek stratejiler geliştirmeleri ve bu çerçevede ingiltere'deki işletmeler ile nasıl iletişime geçeceklerinin planlanması istenmiştir. İşletme, İnovasyon ve Yetenek Bakanlığı bu planların Ulusal İnovatif Satın Alma Politikasına uyumunu gözetmektedir. Bakanlık ayrıca satın alma yetkililerinin eğitimleri üzerinde çalışmaktadır. Bu eğitimler Kamu İhale Kurumu (Government Procurement Service) ile işbirliği kapsamında gerçekleştirilmektedir.

Ulusal İnovatif Satın Alma Politikası uygulamasının orta vadeli hedefleri bakanlıklarda inovatif satın almaya ilişkin farkındalık oluşturulması ve satın almadan sorumlu birimlerin mesleki becerilerinin arttırılması iken uzun vadeli hedefleri işletmelerin inovatif çıktılarının arttırıması ve ulusal inovasyon sisteminin fonksiyonelliğinin arttırılması olarak belirlenmiştir.

Ingiltere'de uygulanan merkezi inovatif satın alma politikası genel inovatif satın alma yöntemi çerçevesinde değerlendirilmektedir. 2011 yılından itibaren İngiltere'de kurulan yeni koalisyon hükümeti bu programın uygulamasını sonlandırmıştır (Uyarra ve diğerleri, 2013: 248).

\subsubsection{Küçük İşletme Araştırma Teşebbüsü Programı (SBRI)}

2001 yılında başlatılan Küçük İşletme Araştırma Teşebbüsü Programı (Small Business Research Initiative Programme-SBRI Programme) ile bakanlıkların dış kaynaklı araştırma projelerinin \%2,5'lik kısmını KOBi'lerden satın almaları zorunluluk haline getirilmiştir. Program, 2008 yılında reforme edilmesi ile 2009 yılından itibaren olmak üzere Avrupa Ticarileştirme Öncesi Satın Alma yaklaşımına uygun bir çerçevede yürütülmektedir.

Program İşletme İnovasyon ve Yetenek Bakanlığı (Department for Business, Information and Skills-BIS) gözetiminde, İngiltere ulusal inovasyon kurumu olan Teknoloji Strateji Kurulu (Technology Strategy Board-TSB) tarafından yönetilmektedir.

Program temel olarak iki aşamadan oluşmaktadır. Illk aşamada ilgili bakanlıkların belirledikleri intiyaçlar çerçevesinde geliştirilen proje önerileri arasında seçilen projelere fizibilite çalışmalarının yapılması için süresi maksimum 6 ay olmak üzere 50.000 euro ile 100.000 euro arasında değişen tutarlarda mali kaynak aktarılmaktadır. İkinci aşamada seçilen projelere prototip çalışmalarının yapılması için süresi maksimum 2 yıl olmak üzere 250.000 euro ile 1.000 .000 euro arasında değişen tutarda mali kaynak aktarılmaktadır.

Buna göre İngiltere'de uygulanan SBRI programı ticarileştirme öncesi inovatif satın alma yöntemini uygulamaktadır. Programda prototipi üretilen projelerin 
ticarileştirilmesi kapsamında herhangi bir mekanizma uygulanmamaktadır. Bununla birlikte SBRI Programında tek alıcı bakanlıklar, diğer bir deyişle, kamu sektörü olduğundan, program ile doğrudan inovatif satın alma yönteminin kullnıldığı belirtilebilir. Program, toplumsal problemlere çözüm üretilmesi, KOBilerin inovatif güçlerinin arttırılması gibi temel stratejilere odaklanmaktadır. Bu bakımdan SBRI Programı stratejik satın alma yöntemi çerçevesinde de değerlendirilebilir.

\subsubsection{Gelecek Taahhüdü Satın Alma (Forward Commitment Procurement)}

Çevre, Gıda ve Köy İşleri Bakanlığı (Department for Environment, Food and Rural Affairs-DEFRA) 2007 yılında yayınladı̆̆ı İngiltere Sürdürülebilir Satın Alma Eylem Planı ile sürdürülebilir satın almanın ilkelerini belirlemiştir. Bu planın temelini Gelecek Taahhüt Satın Alması (Forward Commitment Procurement-FCP) oluşturmaktadır. FCP Modeli; sonuç odaklı olarak tanımlanmış ihtiyaçların satın alınmasına dayalı bir satın alma modelidir. Bu model sayesinde piyasanın maliyet-etkin inovatif çözümler üretebilmesi beklenmektedir. Model DEFRA ve BIS işbirliği çerçevesinde yürütülmektedir (Brenton ve diğerleri, 2011: 36).

FCP Modeli, kamu kurumunun ihtiyaç duyduğu ürün veya hizmetin piyasada bulunmaması veya satın alması için çok pahalı olduğu durumlarda uygulanmaktadır. Buna göre modelin temel özelliği, piyasa ile önceden iletişim kurulurak, piyasanın ürettiği prototipin ihtiyaca uygun olması durumunda, söz konusu ürün veya hizmetin sipariş edileceği ve satın alınacağı garantisinin verilmesidir. Buna göre FCP Modeli; i) ihtiyaçların tanımlanması, ii) piyasaya taahhüt verilmesi ve iii) satın almanın gerçekleştirilmesi şeklinde sıralanan üç aşamadan oluşmaktadır.

Bu aşamalar aracılığıyla, FCP piyasanın kamı ihtiyaçları konusunda farkındalığı arttırılmaktadır (BIS, 2011). Bununla birlikte FCP inovasyon yatırımı konusunda piyasa riskini de azaltmaktadır (Uyarra ve diğerleri, 2013: 251).

FCP Modeli ile piyasanın dönüştürülmesini amaçladığından stratejik inovatif satın alma yöntemi çerçevesinde değerlendirilmektedir. Bununla birlikte FCP Modeli ile ticarileştirme öncesi inovatif satın alma ile ticarileştirilmiş ürünlerin satın alınması mümkündür.

\subsubsection{Kamu-Özel Satın Alma Anlaşması (Public-Private Procurement Compacts)}

2012 yılında BIS Kamu-Özel Satın Alma Anlaşması programını başlatmıştır. Programın temel amacı büyük kamu ve özel sektör kurumlarının ürün ve süreçlerin satın alınmasında güç birliği yaparak karbon ayak izinin azaltılmasıdır. Kurumlar sadece taleplerini birleştirmekle kalmamakla, aynı zamanda uzun vadeli taleplerin belirlenmesinde ortak bir yol haritası çizmekte ve inovasyonun üretilmesi ve difüzyonu konusunda sanayiye açık sinyaller göndermektedir (Uyarra ve diğerleri: 2013: 252).

İngiltere'deki bu uygulama inovatif satın alma yöntemlerinden işbirlikçi satın alma yöntemi çerçevesinde değerlendirilmektedir. 


\subsection{Hollanda}

\subsubsection{Küçük İşletme ve İnovasyon Araştırma Programı}

Küçük İşletme ve İnovasyon Araştırma Programı (The Small Business and Innovation Research Programme- SBIR) Hollanda'da 2003 yılından itibaren uygulanmaktadır. Program; i) toplumsal sorunlara inovatif çözümler getirilmesi, ii) işletmelerde - özellikle KOBi'lerde- inovasyonun teşvik edilmesi, iii) bilginin değerlemesi ve geliştirilmesi amaçlanmaktadır.

Programın farklı uygulama biçimleri mevcuttur. Program inovatif satın alma türleri itibariyle değerlendirildiğinde, ticarileştirme öncesi satın alma yöntemini Bununla birlikte programın toplumsal sorunlara inovatif çözümler üretilmesi ve KOBI'lerin inovasyon kapasitelerinin güçlendirilmesi amaçlarını taşıması sebebiyle, program stratejik satın alma yöntemini benimsemektedir. Uygulamada kamu kesiminin tek alıcı durumunda olması doğrudan satın alma yöntemi içerisinde değerlendirilmesine sebep olmaktadır (Stuyt, 2011).

\subsubsection{Inovasyon Odaklı Satın Alma Programı}

Hollanda Ekonomik İşler Bakanlığı (Ministry of Economic Affairs) 2006 yılında Müşteri Olmak (Launching Customer) Programıla kamu satın almasının inovatif ürünlerin oluşturulması, geliştirilmesi ve piyasalarının oluşturulması ve toplumsal sorunların çözülmesi amacına hizmet edeceğini açıklamıştır. Programın temel amaçlarından birisi kamunun inovatif ürün ve hizmetlerin ilk müşterisi olması, diğeri ise büyük kamu alımları sayesinde inovasyon konusunda lider bir piyasanın oluşturulması olarak belirlenmiştir. Programın temel faaliyeti politika yapıcıların ve kamu satın alma yetkililerinin bilgilendirilmesi ve farkındalıklarının sağlanması olmuştur. 2009 yılında, programın adı İnovasyon Odaklı Satın Alma (Innovation-Driven Procurement) olarak değiştirilmiştir. Programın amacı kamu kurumlarının inovatif çözümler üretilmesini sağlaması olarak belirlenmiştir. Program sorumlusu Ekonomik İşler Bakanlığı olarak belirlenmiş ve programın merkezi inovatif satın alma, sürdürülebilir inovatif satın alma ve SBIR programlarının koordinasyonunu gerçekleştireceği ve Bakanlığın satın alma kuruluşu PIANOo ile işbirliği içerisinde çalışacağı beyan edilmiştir. Merkezi düzeyde inovatif satın alma uygulamaları bu çerçevede gerçekleştirilmektedir.

İnovatif satın alma sınıflandırması açısından değerlendirildiğinde, program doğrudan herhangi bir satın alma gerçekleştirmek yerine kamu kuruluşlarının satın alma rollerini geliştirmeyi hedeflemesi sebebiyle genel inovatif satın alma kapsamında değerlendirilmektedir. Ancak program çerçevesinde bazı bakanlıkların sektörel amaçlar çerçevesinde inovatif satın alımlar gerçekleştirdiği gözönünde bulundurulduğunda, söz konusu bakanlıklar açısından sınıflandırma stratejik ve teknolojik inovatif satın alma kapsamında değerlendirilmektedir (Stuyt, 2011). 


\section{Kamu İnovastif Satın Alma Politikası İle İ gili Sorunlu Alanlar ve Çözüm Önerileri}

Kamu inovatif satın alma politikası uygulamalarından iki temel etki elde edilmesi beklenmektedir. Bunlardan birincisi yeni ürün ve hizmetlere ilişkin talebin kamu kesimi tedarikçilerinin inovasyon arzını geliştirmesidir. İkincisi ise inovatif ürün ve hizmetlerin kamu kesimi tarafından satın alınması neticesinde, kamu hizmetlerinin kalite, verimlilik ve etkinlik kriterleri açısından gelişmesi ve gelecek toplumsal ihtiyaçların daha etkili yöntemlerle karşılanmasıdır (Valovirta, 2015: 66). Bununla birlikte kamu kesimi ile kamu kesimi tedarikçileri arasındaki bu etkileşimin yeni piyasalar oluşturması, dolayısıyla büyüme ve kalkınmanın sağlanması gibi pozitif etkiler yaratması beklenmektedir.

Ancak uygulamada kamu inovatif satın alma yöntemlerinden Ar-Ge satın almasına ağırlık verildiği görülmektedir. Edquist (2013: 10)'e göre Ticarileştirme öncesi satın alma beklenen araştırma sonuçlarının satın alınmasıdır. Yeni bir ürünün ortaya konması ticarileştirme öncesi satın alma yönteminin bir parçası değildir. Buna göre ticarileştirme öncesi satın alma Ar-Ge faaliyetlerinin fonlanmasından ibaret olduğundan arz yanlı inovasyon politikaları kapsamında ele alınmalıdır. Bu yöntemde araştırma sonrasında ürünün ticarileştirilmesi işi ilgili işletmenin omuzlarına bırakılmaktadır (Edquist, 2013: 10).

Inovasyon dostu satın alma ise yeni ve inovatif çözümlerin dışlanmamasını öngören uygulamaları ifade eder. Buna göre inovasyon dostu satın alma inovatif satın alma yönteminde olduğu gibi inovasyonun satın alınmasını öngörmez, ancak inovasyonun geliştirilmesini teşvik eder (Edquist ve diğerleri, 2015: 7, 8).

Edler ve diğerleri (2015:54-56) tarafından 2011 Mayıs ve Haziran aylarında, Ingiltere' de 800 yönetici ile gerçekleştirilen araştırmaya göre, inovasyonun önündeki engeller önemlilik sırasına göre, i) kamu satın alma sürecinde aşırı fiyat odaklı olunması, ii) inovasyonun yüksek maliyetler gerektirmesi, iii) inovasyon talebinin düşük olması, iv) satın alma profesyonellerinin risk tutumu, zayıf risk yönetimi ve satın alma personelinin piyasa ve teknoloji bilgisi açısından yetersizliği, v) kamu satın alma birimi ile tedarikçiler arasındaki yetersiz iletişim şeklinde ortaya koyulmuştur. Araştırmanın bir diğer sonucu ise uzun ve detaylı sözleşmelerin inovasyonu daha fazla tetiklediği algısı olarak ortaya çıkmıştır.

Tsipouri (2015: 5-6) kamu inovatif satın alma politikasının önündeki en önemli engelleri i) satın almanın geleneksel baskın özellikleri ve değişime olan direnç, ii) inovatif satın almada gerekli olan operasyonel yetenek, iii) inovatif satın alma sürecinin riskleri şeklinde üçlü bir sınıflandırmaya tabi tutarak değerlendirmiştir.

Buna göre kamu satın alma süreci geleneksel olarak fiyat ve rekabet odaklıdır. $\mathrm{Bu}$ sayede kamu harcamaları artışının önüne geçileceği düşünülür. Satın alma profesyonelleri de kariyerlerini kamu satın alma sürecinin bu iki temel geleneksel dinamiği üzerine kurar. Bu durum inovatif ihtiyaçların toplanmasını, gelecek ihtiyaçlar hakkında tedarikçilerle iletişim kurmayı, tedarikçilerle işbirliği kurmayı engeller. 
Bununla birlikte geleneksel satın alma mentalitesinden inovatif satın almaya geçiş daha fazla operasyonel ve yönetsel yetkinlik gerektirir. İnovatif satın almanın ihtiyaç duyduğu yetkinliklere kısa vadede ulaşılması kamu bürokratik kültürü açısından kolay değildir.

Öte yandan inovatif satın alma süreci bünyesinde pek çok riski barındırır. Teknolojik risk inovatif ürünün tamamlanmaması, düşük performans göstermesi, yanlış performans göstermesi (istenen fonksiyonlara sahip olmaması) anlamına gelir. Piyasa riskli talep veya arz kaynaklı olabilir. Finansal risk maliyetlerin tahminleri aşması şeklinde ortaya çıkabileceği gibi uzun vadeli proje döngülerinin inovatif satın alma sürecinin tamamlanmasını engellemesi şeklinde ortaya çıkabilir. İnovatif satın alma sürecinin başarısızlığa uğraması kurumsal risk ve inovatif ürünün kabul görmemesi toplumsal risk şeklinde kendini gösterir.

Georghiou ve diğerleri (2012: 35-36): inovatif satın almanın önündeki engelleri i) yapısal koşullar, ii) organizasyon ve yetkinlik, iii) ihtiyaçların belirlenmesi ve iletilmesi, iv) inovatif çözümlerin teşvik edilmesi şeklinde gruplandırarak ele almışlardır.

Buna göre i) satın alma ile ilgili yasal düzenlemelerin inovasyon yerine fiyat rekabetine önem vermesi, ii) kamu ihalelerinin KOBi'leri dezavantajlı duruma düşürmeleri sorunu yapısal koşullar başlığı altında ele alınmıştır. Organizasyonel ve yetkinlik ile ilgili sorunlar ise i) Satın alma ile ilgili kurumlarda/birimlerde inovasyon potansiyeli veya inovasyon stratejisi hakkında farkındalık eksikliği ile ii) Satın almadan sorumlu kişilerin inovasyon dostu uygulamalar hakkında yeterli yetkinliğe sahip olmamaları şeklinde sıralanmıştır.

Ihtiyaçların belirlenmesi ve iletilmesi ile ilgili sorunlar kapsamında i) inovatif ürünlerin nihai kullanıcıları, aracıları ve satın alma fonksiyonu arasındaki yetersiz iletişim ile ii) tedarikçinin inovasyon potansiyeli hakkındaki yetersiz bilgi sorunları değerlendirilmiştir. İnovatif çözümlerin teşvik edilmesi sorunları kapsamında ise i) inovatif ürünün sahiplenilmeme riski ile ilgili sorunlar ile ii) satın alma birimlerinin risk tutumu sorunları ele alınmıştır.

Ülke uygulamaları ve bu konuda yapılmış teorik çalışmalar (Tsipouri, 2015: 7-8, Georghiou, 2012: 35-36) göz önüne alındığında bu sorunlara karşılık çözüm önerileri;

i) İnovasyon dostu yasal düzenlemelerin gerçekleştirilmesi,

ii) KOBi'lerin ihale başvuru süreçlerinin ve şartlarının basitleştirilmesi ve kolaylaştırılması,

iii) İnovatif satın alma sürecine yön veren üst politika stratejilerinin oluşturulması,

iv) Eğitim takvimlerinin, uygulama rehberlerinin ve başarılı uygulamaların paylaşıldığı ağların oluşturulması,

v) Inovatif satın alma sürecinin getirdiği ilave maliyetlere mali destek sağlanması, 
vi) Çözümlerin gösterilmesi için ticarileştirme öncesi satın alma yöntemi ile ArGe faaliyetlerinin desteklenmesi,

vii) Tedarikçi ve kullanıcıların bir araya getirildiği inovasyon platformlarının oluşturulması, piyasa çalışmalarının yapılması, sertifikasyon ve standardizasyon çalışmalarının yapılması,

viii) Inovasyonun satın alınacağının/sertifikalandırılacağının garantisinin verilmesi, fiyat garantisinin verilmesi

ix) Özel bir sigorta mekanizmasının kurulması şeklinde ortaya çıkmaktadır.

\section{Sonuç}

Kamu inovatif satın alma politikası yöntemlerinin ve seçilmiş ülke uygulamalarının incelendiği bu çalışmada inovatif satın alma politikasının uygulanmasında görülen genel eğilimlere, uygulamada karşılaşılan sorunlar ve bu sorunlara yönelik çözüm önerilerine yer verilmiştir.

Buna göre kamu inovatif satın alma politikasının uygulanması ile i) kamu kesiminin inovatif ürün ve hizmetlere ilişkin talebinin piyasa arzını geliştirmesi, ii) kamu hizmetlerinin niteliğinin geliştirilmesi, iii) yeni piyasaların oluşturulması sureti ile rekabet edebilirliğin, büyüme ve kalkınmanın sağlanması beklenmektedir. Ancak uygulamada görülen temel eğilim kamu inovatif satın alma politikasının Ar-ge satın alması, bir başka deyişle ticarileştirme öncesi satın alma şeklinde gerçekleştirilmesidir. $\mathrm{Bu}$ durum inovatif ürün ve hizmetin satın alınması yerine Ar-ge faaliyetlerinin desteklenmesi şeklinde anlaşıldığından, inovatif satın alma politikasından beklenen faydaların gecikmesine sebep olabilecek potansiyel riskleri barındırmaktadır. Bununla birlikte aslında bu genel eğilim gelişmiş ülkelerin de kamu inovatif satın alma politikasını öğrenme sürecinden geçtiğine ve özel sektörü kamu inıvatif satın alma talebine hazır hale getirmeye çalıştığına işaret etmektedir.

Ülke uygulamalarında görülen bir diğer eğilim ise КОВi’lere yönelik özel inovatif satın alma politikalarını uygulamaları şeklinde görülmektedir. Ülkemizde de sanayi sektörünün büyük bir kısmının KOBi’lerden oluştuğu göz önüne alındığında bu genel eğilime paralel uygulamaların benimsenmesi bir öneri olarak ortaya koyulabilir.

Bununla birlikte ülke uygulamalarında kamu inovatif satın alma politikasının uygulanmasında hem merkezi idarelere hem de adem-i merkezi yapılanmalara yer verdiği görülmektedir. Ayrıca kamunun özel sektör ile etkileşimin arttırılmasında bakanlıklar arası koordinasyon birimlerinin oluşturulduğu görülmektedir.

Çalışmada bu genel eğilimlerin saptanmasının yanı sıra uygulamada karşılaşılan güçlüklere ve bu güçlüklerin aşılmasında ortaya koyulan çözüm önerilerine konuyla ilgili literatürden de faydalanılarak yer verilmiştir. Buna göre kamu inovatif satın alma politikasının önündeki engeller; i) satın alma ile ilgili düzenlemelerin inovasyon yerine fiyat rekabetine önem vermesi, ii) kamu ihalelelerinin KOBI'leri dezavantajlı duruma düşürmeleri sorunu, iii) satın alma ile ilgili birimlerde inovasyon potansiyeli veya 
inovasyon stratejisi hakkında farkındalık eksikliği, iv) satın almadan sorumlu kişilerin inovasyon dostu uygulamalar hakkında yeterli yetkinliğe sahip olmamaları, v) inovatif ürünlerin nihai kullanıcıları, aracıları ve satın alma fonksiyonu arasındaki yetersiz etkileşim, vi) tedarikçinin inovasyon potansiyeli hakkındaki yetersiz bilgi sorunları, vii) inovatif ürünün sahiplenilmeme riski ile ilgili sorunlar, viii) satın alma birimlerinin risk tutumu ile ilgili sorunlar şeklinde ortaya koyulmaktadır.

Uygulamada karşılaşılan bu engellere karşılık; i) inovasyon dostu yasal düzenlemelerin gerçekleştirilmesi, ii) KOBi'lerin ihale başvuru süreçlerinin ve şartlarının basitleştirilmesi ve kolaylaştırılması, iii) inovatif satınalma sürecine yön veren üst politika stratejilerinin oluşturulması, iv) eğitim takvimlerinin, uygulama rehberlerinin ve başarılı uygulamaların paylaşıldığı ağların oluşturulması, v) inovatif satın alma sürecinin getirdiği ilave maliyetlere mali destek sağlanması, vi) çözümlerin gösterilmesi için ticarileştirme öncesi satın alma yöntemi ile ar-ge faaliyetlerinin desteklenmesi, vii) tedarikçi ve kullanıcıların bir araya getirildiği inovasyon platformlarının oluşturulması, piyasa çalışmalarının yapılması, sertifikasyon ve standardizasyon çalışmalarının yapılması, viii) inovasyonun satın alınacağının ve/veya sertifikalandırılacağının fiyat garantisinin verilmesi, ix) özel bir sigorta mekanizmasının kurulması şeklinde sıralanan çözüm önerileri ortaya koyulmaktadır. 


\section{KAYNAKÇA}

ALBENI, M., KARAÖZ, M. (2003), "Bölgesel Kalkınmada Öğrenme, Bilgi Birikimi ve Yenilik: Türkiye İçin Bir Perspektif", Süleyman Demirel Üniversitesi iiBF Dergisi, C. 8, S. 2, ss.157-70.

ANDES, S. (2010), "Buying Innovation: How Public Procurement Can Spur Innovation", The Information and Innovation Foundation, October.

ASCHHOFF, B., SOFKA, W. (2008), "Innovation of Demand- Can Public PProcurement Drive Market Success of Innovationa", ZEW Discussion Paper, Discussion Paper No. 08- 052, July.

BRENTON J., DAWAR K., KUNTZE, J.C. (2011), "Issues and Tensions in Public Procurement of Green Innovation: A Cross Country Study", CTEI Working Paper, CTEI-2011-09.

BURMAOĞLU, S., POLAT, M., KÖSE, E. ve APLAK, H. S. (2010), "Kamu Tedarik Sisteminde Dönüşüm: Yenilikçi Satın Alma Politikaları ve $A B^{\prime}$ ye Giriş Sürecinde Türkiye Üzerine Bir Değerlendirme", KHO Bilim Dergisi, C. 20, S. 2, ss.1-21.

DULUPÇU, M.A. (2006), "Bölgesel Politikalar Kopyalanabilir Mi? Bölgeselleş(tir)me (Yönetim) Karşısında (Yeni) Bölge(sel)cilik (Yönetişim)", Bölgesel Kalkınma ve Yönetişim Sempozyumu Bildiriler Kitabı (7-8 Eylül), ss.233-56.

EDLER, J., GERORGHIOU, L. (2007), "Public Procurement and Innovation- Resurrecting the Demand Side", Research Policy, 36, pp.949-63.

EDLER, J. ve diğerleri (2015), "The Meaning and Limitations of Public Procurement for Innovation: A Supplier's Experience", içinde: içinde: Public Procurement for Innovation, (ed. Charles Edquist ve diğerleri), Edward Elgar Publishing, UK.

EDQUIST, C. ve diğerleri (2015), "Introduction", içinde: içinde: Public Procurement for Innovation, (ed. Charles Edquist ve diğerleri), Edward Elgar Publishing, UK.

EDQUIST, C. (2013), "Innovation Procurement: What Is It and What Does It Mean for Grand Challanges, Growth and Employment", Keynote Speech at Expert Workshop on the Measurement of Public Procurement of Innovation, February.

EDQUIST, C. (2009), "Public Procurement for Innovation (PPI)- A Pilot Study", CIRCLE Working Paper, Working Paper No. 2009/13, December.

EDQUIST, C., HOMMEN, L. (1998), Government Technology Procurement and Innovation Theory, March.

ELÇi, Ş., KARATAYLI, i. ve KARATA, S. (2008), Bölgesel İnovasyon Merkezleri: Türkiye İçin Bir Model Önerisi, TÜsiAD Yayını, Yayın No: TÜSiAD-T/2008-12/477, Aralık, İstanbul.

EUROPEAN COMMISSION (2015), Innovation Procurement Around EU Levels, http://ec.europa.eu/digital-agenda/en/news/innovation-procurementinitiatives-around-europe, (10.10.2015). 
GAVRAS, A. ve diğerleri (t.y.), Procurement as an Innovation Instruments, INNOUTLITIES, (http://www.inno-utilities.org/public/Documents/Inno-UtilitiesBook.pdf)

GEORGHIOU, L. ve diğerleri (2014), "Public Procurement as Innovation Policy Tool: Choice, Design and Assessment", Technological Forecasting and Social Change, Vol. 86, 1-12.

GÜÇERI, i., KARAMAN, M. A. (2013), "Vergi İndirimlerinin Özel Sektör Ar-Ge Stratejisindeki Rolü", T.C. Bilim, Sanayi ve Teknoloji Bakanlığı 3. Sanayi Şurası (20-21-22 Kasım), Ankara, ss.1-12, (www.sanayisurası.gov.tr/?sunumlar).

IŞIK, N., KILINÇ, E. C. (2011), "Bölgesel Kalkınmada Ar-Ge ve İnovasyonun Önemi: Karşılaştırmalı Bir Analiz”, Eskişehir Osmangazi Üniversitesi iiBF Dergisi, Ekim, 6(2), ss.9-54.

iZKA (2012), İzmir Bölgesel Yenilik Stratejisi, İzmir.

KALKINMA BAKANLIĞı (2013), Onuncu Kalkınma Planı (2014-2018), Ankara.

KARA, M. (2008), Bölgesel Rekabet Edebilirlik Kavramı ve Bölgesel Kalkınma Politikalarına Yansımaları, DPT Ekonomik Modeller ve Stratejik Araştırmalar Genel Müdürlüğü Uzmanlık Tezi, Yayın No: DPT: 2774, Ankara.

KATTEL, R., LEMBER, V. (2010), "Public Procurement as an Industrial Policy Tool: An Option for Developing Countries?", Journal of Public Procurement, Vol. 10, Issue 3, Fall, pp.368-404.

KESKIN, H., SUNGUR, O. (2010), "Bölge Politika Ekseninde Yaşanan Dönüşüm: Türkiye'de Kalkınma Planlarında Bölgesel Politikaların Değişimi”, Munich Personal RePEc Archive Paper, No. 46574, May, ss.1-22.

KUMRAL, N. (2006), “Bölgesel Rekabet Gücünü Arttırmaya Yönelik Politikalar”, Bölgesel Kalkınma ve Yönetişim Sempozyumu Bildiriler Kitabı (7-8 Eylül), ss.275-87.

LENGER, Aykut (2006), "Bölgesel Yenilik Sistemleri ve Devletin Rolü: Türkiye'deki Kurumsal Yapı ve Devlet Üniversiteleri",

(http://www.onlinedergi.com/MakaleDosyalari/51/PDF2006_2_13.pdf), ss.141-55.

NYRI, L., OSIMO, D., ÖZCIVELEK, R., CENTENO, C. ve CABRERA, M. (2007), Public Procurement for the Promotion of R\&D and Innovation in ICT, EUR 22671 EN, Spain.

OECD (2009), How Regions Grow?, OECD Policy Brief, March.

OECD (2004), OSLO Manual The Measurement of Scientific and Technological Activities,

ÖZER, Y. E. (2007), "Küresel Rekabet-Bölgesel Kalkınma Ajansları ve Türkiye”, Review of Social, Economic and Business Studies, Vol. 9/10, pp.389-408.

ROLFSTAM, M. (2014), Public Procurement as a Means to Stimulate Innovation for a Better World: A Matter of Knowledge Management", Paper Prepared For The 3rd Lundvall Symposium (13-14 March), Utzon Center, Aalborg, Denmark. 
ROLFSTAM, M. (2012), "An Institutional Approach to Research on Public Procurement of Innovation", The European Journal of Social Science Research, 25(3), pp.303321.

SAKAL, M. (2010), Bölgesel Kalkınma Sürecinde Kalkınma Ajansları, Altın Nokta Yayınevi, İzmir.

Sanayi ve Ticaret Bakanlığı (2007), Bölgesel Rekabet Edebilirlik Operasyonel Programı, Ankara, Ekim.

STUTY, C. (2011), Public Procurement for Innovation as a Tool for Stimulating Sustainable Innovation- A Cross Country Comparison, Master Thesis Under Joint Supervision of Utrecht University and The Internatiınal Institute for Industrial Environmentall Economics at Lund University, August.

THE KONKURRENSVERKET (2015), News: The Swedish Competition Agency and VINNOVA Collaborate on Innovation Procurement, http://www.konkurrensverket.se/en/new/the-swedish-competition-authorityand -vinnova-collaborate-on-innovation-procurement/, (10.10.2015).

TUNCEL, C. O., BAKIR, H. (2010), "Yenilik Temelli Bir Bölgesel Gelişme Sürecinde Kalkınma Ajanslarının Yeri", İ̧̧letme ve Ekonomi Araştırmaları Dergisi, C. 1, S. 4, ss.19-41.

TSIPOURI, L. (2015), "Public Procurement of Innovation" EC Innovation for GrowthPolicy Brief Policy Brief No. 2, http://wc.europa.eu/research/innovationunion/pdf/expert-groups/i4g-reports/i4g_policy_brief_2_-_public_ procurement.pdf, (10.10.2015).

UK Department for Environment, Food and Rural Affairs (2006), Procuring the Future Sustainable Procurement National Action Plan: Recommendations from the Forward Commitment Procurement Sustainable Procurement Task Force, DEFRA, London.

UK Department for Business, Innovation and Skills (2011), Delivering Best Value Through Innovation: Forward Commitment Procurement, BIS, London, URN $11 / 1054$.

UK Technology Strategy Board (2015), Innovate UK, May.

UYARRA, E. ve diğerleri (2013), "Public Procurement of Innovation: The UK Case", içinde: Public Procurement, Innovation and Policy, (ed. Veiko Lember and Tarmo Kalvet),Springer.

ÜNÜBOL, N. (2012), Kamu Alım Piyasalarının Etkinliğinde Rekabetin Rolü: Rekabetin Korunması, Sağlanması ve Rekabet Savunuculuğu, Rekabet Kurumu Uzmanlık Tezleri Serisi No: 119, Ankara.

WAYERMEYER, R. (2010), "Linking Developmental Delivarables to Public Sector Contracts", paper presented at Workshop on Designing Efficient Public Procurement Policies to Foster Technology Transfer and Development Capacity in Emerging Markets (1-2 October), İstanbul. 
WINTJES, R. (2011), "Demand-Side Innovation Policy at Regional Level", October, Brussels, (http://www.isi.fraunhofer.de/isi-wAssets/docs/p/de/events/rim_ workshop_10-2011/5_demand-side_innovation_policy_at_regional_level.pdf)

VALOVIRTA, Ville (2015), "Building Capability for Public Procurement of Innovation", içinde: Public Procurement for Innovation, (ed. Charles Edquist ve diğerleri), Edward Elgar Publishing, UK.

VECCHIATO, R., ROVEDA, C. (2014), "Foresight for Public Procurement and Regional Innovation Policy: The Case of Lombardy", Research Policy, 43, pp.438-50.

VINNOVA (2015), About VINNOVA, http://www.vinnova.se/en/About-VINNOVA, (10.10.2015).

YÜLEK M. A., TíRYAKioĞLU, M. (2013), “Kalkınma Temelli Kamu Alımı Politikaları: Politika Deneyimleri ve Literatürden Seçilmiş Örnekler", T.C. Bilim, Sanayi ve Teknoloji Bakanlığı 3. Sanayi Şurası (20-21-22 Kasım), Ankara, ss.1-12, (www.sanayisurası.gov.tr/?sunumlar). 